\title{
Evaluation of local duck production systems in Imo and Abia States of Nigeria
}

${ }^{1}$ Kadurumba, O. E., ${ }^{1}$ Egenuka, F. C., ${ }^{1}$ Ikpamezie, L. C., ${ }^{2}$ Kadurumba, C. and ${ }^{3 *}$ Onunkwo, D. N.

${ }^{I}$ Department of Animal Science and Technology, Federal University of Technology P.M.B. 1526 Owerri, Imo State Nigeria

${ }^{2}$ Department of Agricultural Extension Management, Federal College of Agriculture

P.M.B. 7008 Ishiagu, Ebonyi State Nigeria

${ }^{3}$ Department of Animal Nutrition and Forage Science,

Michael Okpara University of Agriculture, Umudike, Abia State, Nigeria.

\section{Abstract *Corresponding author: donunkwo1@gmaill.com; 08033388622}

A study was conducted to evaluate local duck production systems in Imo and Abia States of Nigeria. Seventy-two (72) local duck farmers from both States were purposefully selected using snowball sampling techniques and were interviewed using structured questionnaires. Data on farmers' socio-economic characteristics and production practices were collected and analyzed using descriptive statistics such as frequencies, percentages and charts. The results showed that there were more male duck farmers $(88.89 \%)$, while the average age of duck farmers was 51.35years. Most (97.22\%) of the duck farmers were literate, $58.33 \%$ of households had between 4 - 7 members, 73.61\% of duck farmers were christians and a higher number (46.43\%) raised pigs alongside of ducks. Most farmers (98.61\%) kept only Muscovy ducks. The average flock size is about 6-9 ducks per household. Ducks were mainly kept for rituals and traditional medicine (56.78\%). About 48.61\% of farmers used personal money to finance duck farming, while 47.22\% of farmers inherited their foundations stock. The age at sexual maturity for ducks was 7 to 9 months; clutch length was 11 to 15 days, while clutch size ranged from 16 to 20 eggs. Again, 94.44\% of farmers practiced extensive system of duck keeping while $84.72 \%$ did not provide supplementary feeds to their ducks. Accidents are the leading cause of mortality in ducks, while the myths that surround ducks are the main obstacle to duck meat consumption. The results showed that duck farming is not popular in the study area and therefore, ducks are seen and kept as sacrificial birds. Thus, the potential of ducks for the production of meat and eggs is not fully exploited. These myths that have hindered the production of ducks could be dispelled through farmer trainings and enlightenment.

Keywords: duck, myth, production, conservation

\section{Introduction}

In Nigeria, chickens have received much more awareness than any other poultry specie and equally popular in the poultry egg and meat segment. Ducks are a crucial element of various human societies around the world and can be an alternative to chicken in egg and meat production while at the same time, increase dietary protein intake of an average Nigerian to the standard recommended by the United Nations Food and Agriculture Organization
(FAO) (Ige et al., 2014). Local ducks perform well in a scavenger system because they have an exceptional ability to feed on materials that are neither useful to humans nor can be salvaged by chickens and other domestic animals (Banga-Mboko et al., 2007). These ducks are also more resistant to diseases than chickens and are very promising among native poultry species because of their relatively fast growth rate and the high weight of dressed drakes (Duru et al., 2006). However, its production has 


\section{Evaluation of local duck production systems in Imo and Abia States of Nigeria}

been hampered by the myths, taboos and cultural beliefs that surround it. Ducks are part of the prejudiced, less exploited and underutilized poultry species in Nigeria despite their inherent potential for meat and egg production. Its declining numbers in recent years further prove that this bird has been neglected in terms of production and conservation (FAO, 1999; Oguntunji, 2013). Again, due to their scavenging feeding habit, ducks have also been erroneously indicted by the uneducated and ill-informed populace for having a high load of internal worms thereby discouraging its production and consumption.

Currently, the exact production potential of local ducks in southeastern Nigeria remains unknown (Okeudo et al., 2003) and therefore needs to be studied in order to generate the information needed for improvement studies. To improve the production potential of the duck, its production environment must be well understood. Therefore, this study aimed to evaluate local duck production system in Imo and Abia States of Nigeria with a view to providing relevant information to improve the production and conservation of these ducks.

\section{Methodology}

The study was conducted in Imo and Abia States of Nigeria. The area is located in a lowland area of $\Theta \Theta$ the agro-ecological zone of Nigeria's rainforest at latitude $5^{0} 45^{1} \mathrm{~N}$ and longitude $8^{0} 30^{1} \mathrm{E}$. Imo State has an average annual rainfall which varies from 1980 to $2700 \mathrm{~mm}$. Mean annual minimum and maximum temperatures range from $19^{\circ} \mathrm{C}$ to $24^{\circ} \mathrm{C}$ and from $30^{\circ} \mathrm{C}$ to $35^{\circ} \mathrm{C}$, with an annual relative humidity of up to $90 \%$ during the rainy season (NBS, 2010). Abia State has an annual rainfall of $2177 \mathrm{~mm}$ per annum, with a relative humidity of about $50-90 \%$ and temperature range of $22^{\circ} \mathrm{C}-36^{\circ} \mathrm{C}$ (Meteorological Station, NRCRI, Umudike, 2018). Two agricultural zones in each State and three Local Government Areas in each agricultural zone were selected on purpose. Due to the non-popularity of duck farmers in the region, the snowball sampling method was adopted: duck farmers were identified by asking other duck farmers to give references to other duck farmers they know (Nyoni and Masika, 2012). Thus, a total of seventy-two duck farmers were interviewed for this study. A simple structured questionnaire was designed to obtain correct information from farmers about their duck production practices. Farmers were interviewed individually, and the data were collected using the survey questionnaire. The data were subjected to descriptive statistics such as frequencies, percentages, graphs and averages using statistical software for the social sciences (SPSS 2010).

\section{Results and discussion Socio-economic characteristics of duck farmers}

The socioeconomic characteristics of duck farmers are presented in Table 1. Male duck farmers accounted for $88.89 \%$ of the total duck farmers. The low participation of women in this study may be due to the myths and taboos surrounding duck production in the region. This observation is consistent with the findings of BangaMboko et al. (2007) and FAO (2009a; 2009b), Alfred and Agbede (2012) in southwestern Nigeria, who reported a high number of male duck farmers compared to women. In a contrary study, Ogah and Momoh (2013) reported that women were the main custodians of ducks in northcentral Nigeria. 
Kadurumba, Egenuka, Ikpamezie, Kadurumba and Onunkwo

Table 1 : Socio-economic characteristics of duck farmers

\begin{tabular}{|c|c|c|c|}
\hline \multirow[t]{2}{*}{ Parameters } & \multicolumn{3}{|c|}{ Farmers $(\%)(\mathrm{N}=72)$} \\
\hline & Imo & Abia & Average \\
\hline \multicolumn{4}{|l|}{ Sex } \\
\hline Male & 83.33 & 96.67 & 88.89 \\
\hline Female & 16.67 & 3.33 & 11.11 \\
\hline \multicolumn{4}{|c|}{ Educational level } \\
\hline No schooling & 2.39 & 3.33 & 2.78 \\
\hline Primary & 33.33 & 40.00 & 36.11 \\
\hline Secondary & 52.38 & 43.33 & 48.61 \\
\hline Tertiary & 11.90 & 13.33 & 12.50 \\
\hline \multicolumn{4}{|l|}{ Age } \\
\hline $31-40$ & 11.90 & 0.00 & 6.94 \\
\hline $41-50$ & 28.57 & 20.00 & 25.00 \\
\hline $51-60$ & 50.00 & 76.67 & 61.11 \\
\hline 61 and above & 9.52 & 3.33 & 6.94 \\
\hline Mean age & & & 51.35 \\
\hline \multicolumn{4}{|l|}{ Household size } \\
\hline $1-3$ & 2.38 & 3.33 & 2.78 \\
\hline $4-7$ & 54.76 & 63.33 & 58.33 \\
\hline $8-10$ & 30.95 & 26.67 & 29.17 \\
\hline$>10$ & 11.90 & 6.67 & 9.72 \\
\hline \multicolumn{4}{|l|}{ Religion } \\
\hline Christianity & 80.95 & 63.33 & 73.61 \\
\hline Islam & 0.00 & 0.00 & 0.00 \\
\hline Traditionalist & 9.53 & 6.67 & 8.33 \\
\hline Others & 9.52 & 30.00 & 18.05 \\
\hline \multicolumn{4}{|c|}{ Farmers occupation } \\
\hline Farming & 45.23 & 66.67 & 54.17 \\
\hline Trading & 21.43 & 10.00 & 16.67 \\
\hline Civil servants & 9.53 & 6.67 & 8.33 \\
\hline Others & 23.81 & 16.66 & 20.83 \\
\hline
\end{tabular}

Most farmers (61.11\%) were aged between 51 and 60 years of age, while the average age of duck farmers was 51.35 years. This observation was consistent with the findings of Banga-Mboko et al. (2007) and Ogah and Momoh (2013) that reported duck farming to be more common among middle-aged people. The ages of farmers recorded in this study were not favorable for the production and conservation of ducks, this is because the risk-taking abilities, ability to be innovative and the mental capability to cope with the daily challenges and demands of duck management decreases with age. The level of literacy among farmers indicates that $97.22 \%$ of them can read and write. This result is important for the improvement and conservation of ducks as education and training are essential to improve the ability of farmers to understand and accept technological innovations that will eventually lead to increased and sustainable production of ducks (Nwaru, 2001). Most duck farmers $(58.33 \%)$ had a household size of 4-7 members. This observation is consistent with the findings of Ogah and Momoh (2013) and Okoil et al. (2004) 


\section{Evaluation of local duck production systems in Imo and Abia States of Nigeria}

reported an average household size of 4-7 members among North Central duck farmers and poultry farmers in Nigeria, respectively. The dominant religion recorded was Christianity (73.61\%) and, although Christianity was popular, duck production was still surrounded by myths, folklore and taboos that portrays the duck mainly as a sacrificial bird used for cultural purposes, traditional medicine, burials and spiritual purification (Oguntunji and Ayorinde, 2014). The majority of duck farmers $(49.26 \%)$ raise pigs alongside ducks. This result coroborates the findings of FAO (2009a) that reported $53.3 \%$ of duck farmers also keep pigs alongside ducks. This implies that duck farmers who raised pigs alongside ducks, do not need to provide their ducks with supplementary feeds because pig waste serves as both feed and wallow for ducks (Fig. 1).

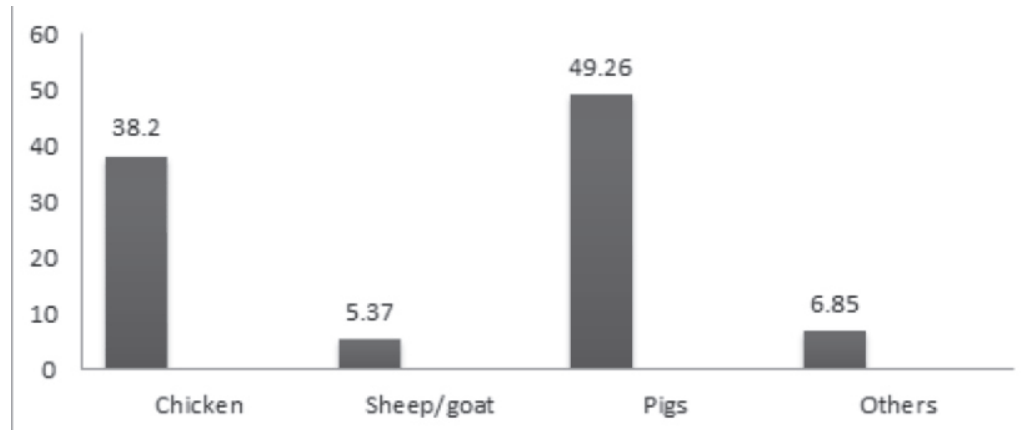

Fig. 1 Distribution of duck farmers according to their livestock inventory

Distribution of breeds, sources of funding and stock of duck breeders

Results for the distribution of breeds, sources of finance and basic stocks in the Imo and Abia States are shown in Table 2. The most predominant local duck breed found in the study area is the Muscovy duck. This result corroborates previous reports by Kadurumba et al. (2015); Oguntunji (2013); Udedibie and Ogbonna (2006); Duru et al. (2006); Etuk et al. (2006) that reported the
Muscovy ducks as the most popular duck breed in Nigeria. The prevalence of these breed of ducks as recorded in this study may be due to their adaptation to the environment and their acceptance by the people. Again, while majority of duck farmers inherited $(47.22 \%)$ or bought $(43.06 \%)$ their foundation stocks, none of the farmers got theirs through donations of ducks or eggs as applicable among chicken farmers (Mogasse, 2007)

Table 2: Breed distribution, sources of finance and foundation stock of duck farmers

\begin{tabular}{|c|c|c|c|}
\hline \multirow[t]{2}{*}{ Parameters } & \multicolumn{3}{|c|}{ Farmers $(\%)(\mathrm{N}=72)$} \\
\hline & Imo & Abia & Average \\
\hline \multicolumn{4}{|l|}{ Breed } \\
\hline Muscovy & 100.00 & 96.67 & 98.61 \\
\hline Others & 0.00 & 3.33 & 1.39 \\
\hline \multicolumn{4}{|c|}{ Sources of foundation stock } \\
\hline Inherited & 42.86 & 53.33 & 47.22 \\
\hline Purchased & 40.47 & 46.67 & 43.06 \\
\hline Others & 16.67 & 0.00 & 9.72 \\
\hline \multicolumn{4}{|c|}{ Source of finance for duck farming } \\
\hline Farm sales & 26.19 & 36.67 & 30.56 \\
\hline Personal money & 50.00 & 46.67 & 48.61 \\
\hline Financial institutions & 0.00 & 0.00 & 0.00 \\
\hline Others & 23.81 & 16.67 & 20.83 \\
\hline
\end{tabular}




\section{Kadurumba, Egenuka, Ikpamezie, Kadurumba and Onunkwo}

This suggests that ducks are not popular in the study area and could possibly be the reason for the low number of duck producers in the study area. This result contradicts the practice among chicken farmers who obtain their basic stock by donating live chickens, hatched eggs and purchases (Mogasse, 2007), thereby raising and increasing the number of chickens, so that even when farmers cannot afford to buy or inherit birds, they are always encouraged to keep the birds they have received as gifts. In addition, while some duck farmers (48.61\%) use their personal money to finance their duck rearing, others come from sources such as family members, friends and loans from co-operatives and savings companies. None of the farmers in the either of the States got their funding from financial institutions, because such opportunities do not exist for smallholder farmers. However, when such opportunities exist, the lending process is so cumbersome that farmers are discouraged and reluctant to turn to such financial institutions for loans or subsidies.

Flock size, duration and purpose of the duck

As shown in Table 3, the average herd size ranged from 6 to 9 ducks. The small flock sizes observed in this study suggest that ducks are kept on a very small scale and are seen as less important when compared to other poultry and farm animals in the study area. This report, however, contradicts the findings of Morduzzaman et al. (2015) who reported the availability of large-scale commercial duck farms with flock sizes ranging from around one hundred to more than a thousand ducks in Bangladesh. Majority of the duck farmers (43.06\%) have kept ducks for as long 3-5 years and this years of experience is extremely beneficial for improving duck production and conservation because agricultural skills could be associated with improvements in farmers' production activities. The years of experience of a duck farmer also provide an indication of the practical knowledge he has gained over the years on how he can overcome the challenges associated with duck farming. Ducks were mainly kept for religious rituals, burials and traditional medicine $(56.78 \%)$. These ducks could be seen scavenging around in several market squares and in the houses of great traditionalist who believe that the duck is a very "powerful bird" and employ them for spiritual purposes.

Table 3 Flock size, duration and purpose of duck keeping

\begin{tabular}{lccc}
\hline Parameters & \multicolumn{3}{c}{ Duck farmers (\%) } \\
\hline \multicolumn{2}{l}{ Imo } & Abia & Average \\
\hline $1-5$ & & & \\
$6-9$ & 19.05 & 23.33 & 20.83 \\
$>10$ & 50.00 & 46.67 & 48.61 \\
Duration of duck keeping (years) & 30.95 & 30.00 & 30.56 \\
$1-2$ & & & \\
$3-5$ & 19.05 & 20.00 & 19.44 \\
$>5$ & 28.57 & 16.67 & 43.06 \\
Purpose of duck keeping & 52.38 & 63.33 & 37.50 \\
Income & & & \\
Consumption & 56.72 & 56.86 & 16.96 \\
Rituals and traditional medicine & 17.91 & 13.73 & 16.10 \\
Others (pets, gifts etc) & 14.93 & 19.61 & 56.78 \\
& 10.45 & 9.80 & 10.16 \\
\hline
\end{tabular}




\section{Evaluation of local duck production systems in Imo and Abia States of Nigeria}

Reproductive performance of local ducks Results on the breeding performance of local ducks in this study are presented in Table 4. Ducks (Male and female) reached sexual maturity between 7 and 9 months of age. The age at sexual maturity of ducks reported in this study is consistent with the findings of Oguntunji et al. (2015) in western Nigeria; Nwanta et al. (2006) in Northern Nigeria; Ola (2000) in southeastern Nigeria and Ogah and Momoh (2013) in north-central Nigeria, each reporting that the age of the first egg in ducks was 7 to 8 months and that sexual maturity was reached between 6 and 8 months for ducks. Age at sexual maturity and season would be affected by the type of management system practiced by farmers (Etuk et al., 2006). Clutch length ranged from 11 to 15 days, with the number of clutch per year varying between 1 and 2 clutch per year. The average clutch size was between 16 and 20 eggs per clutch. The average number of ducklings per hatch ranged from 11 to 15 or more, while the number of ducklings surviving to adulthood ranged from 1 to 5 ducks. Ducks having 3 or more cycles per year may be due to early weaning of ducklings, poor maternal ability, and/or environmental changes (Oguntunji et al. 2015). This result coroborates previous studies by Nwanta et al. (2006); Etuk et al. (2011); Chia and Momoh (2012); Banga-Mboko et al. (2007) and Adeyemi et al. (2008) that reported laying sizes of between 16 and 20 eggs, while Oguntunji and Ayorinde (2015) reported laying sizes of between 3 and 30 eggs. The small clutch sizes reported in this study may be due to a variety of reasons, such as egg theft, predator attacks, seasonal variations, and poor management practices (Oguntunji and Ayorinde, 2015). The small number of ducklings that can survive to adulthood may be due to lack of supplementary feeding, zero vaccination, and lack of shelter for ducks, exposing ducks to predation.

Table 4: Reproductive performance of local ducks

\begin{tabular}{llcc}
\hline & \multicolumn{3}{c}{ Duck farmers (\%) } \\
\cline { 2 - 4 } Parameters & Imo & Abia & Average \\
\hline Age at sexual maturity (month) & & 16.67 & 13.89 \\
$4-6$ & 14.29 & 60.00 & 61.11 \\
$7-9$ & 61.90 & 26.67 & 25.00 \\
$>10$ & 23.81 & & \\
Clutch length (days) & & 3.33 & 4.17 \\
$1-5$ & 4.76 & 16.67 & 19.44 \\
$6-10$ & 21.43 & 43.33 & 40.28 \\
$11-15$ & 38.10 & 36.67 & 36.11 \\
$>16$ & 35.71 & & \\
Number of clutches per year & & 80.00 & 84.72 \\
$1-2$ & 88.10 & 20.00 & 15.28 \\
$3-5$ & 11.90 & & \\
Average clutch size & & 13.33 & 11.11 \\
$5-10$ eggs & 9.52 & 33.33 & 29.17 \\
$11-15$ eggs & 26.19 & 50.00 & 56.94 \\
$16-20$ eggs & 61.90 & 3.33 & 2.78 \\
$>20$ eggs & 2.38 & & \\
No of ducklings per hatch & & 30.00 & 29.17 \\
$1-10$ & 28.57 & 53.33 & 56.94 \\
$11-15$ & 59.52 & 16.67 & 13.89 \\
$>16$ & 11.90 & & \\
No of ducklings surviving to adulthood & & 66.67 & 61.11 \\
$0-5$ & 57.14 & 14.29 & 9.72 \\
$5-10$ & 33.33 & & \\
$>10$ & 9.52 & 125 & \\
\hline
\end{tabular}




\section{Kadurumba, Egenuka, Ikpamezie, Kadurumba and Onunkwo}

\section{Management and feeding practices of duck farmers}

The extensive system of management was predominant in the study area (Table 5) as therewere no form of housing or shelter provided for ducks and most duck farmers $(94.44 \%)$ do not feel that housing is needed for ducks and have achieved better results they have the opportunity to do excavations. Several authors (Adeyemi et al., 2008, Duru et al., 2006 and Ugbomeh, 2002) also reported that the extensive management system was the most prevalent management system practiced by local duck producers in Nigeria. Most of the farmers $(84.72 \%)$ did not provide supplementary feed for their ducks, as these ducks are believed to be able to fend for themselves and that providing supplementary feeds amounts to waste of scarce resources. This contradicts the findings of Banga-Mboko et al. (2007), Oguntunji and Ayorinde (2015) and FAO (2009a) that reported a semi-scavenging system of duck keeping where supplementary feeds were provided during the day and shelter at night.

Table 5: Management and feeding practices of duck farmers

\begin{tabular}{llll}
\hline Parameters & \multicolumn{3}{c}{ Duck farmers (\%) } \\
\cline { 2 - 4 } Management system & Imo & Abia \\
Extensive & 100.00 & 86.67 & 94.44 \\
Semi-intensive & 0.00 & 10.00 & 4.17 \\
Intensive & 0.00 & 3.33 & 1.39 \\
Provision of pool & & & \\
Yes & 11.90 & 6.67 & 9.72 \\
No & 88.10 & 93.33 & 90.28 \\
Provision of drinking water & & & \\
Yes & 61.90 & 63.33 & 62.50 \\
No & 38.10 & 3.67 & 37.50 \\
Supplementary feeding & & & \\
Yes & 4.76 & 30.00 & 15.28 \\
No & 95.24 & 70.00 & 84.72 \\
\hline
\end{tabular}

\section{Health and disease control practices for duck farmers}

The disease and health control practices for local duck farmers (Table 6), shows that ducks rarely fall sick while majority of them $(56.94 \%)$ treat their sick ducks using traditional leaves and herbs (ethnoveterinary), some $(6.94 \%)$, kill and consume sick ducks while others $(23.61 \%)$ sell their sick ducks. Farmers (12.50\%) who do nothing when their ducks are sick do not know about drugs to treat duck diseases.
This observation is consistent with the findings of Oguntunji et al. (2015) and Nyoni and Masika (2012) who reported using ethno-veterinary drugs to treat ducks and/or prevent disease, and it is a widespread practice among duck farmers. Furthermore, all the duck farmers $(100 \%)$ in the study area have never vaccinated their ducks and neither do they have access to veterinary or extension services. This could be attributed to lack of awareness of the availability of duck vaccines on the part of the farmers. 
Evaluation of local duck production systems in Imo and Abia States of Nigeria

Table 6: Health and disease control practices among duck farmers

\begin{tabular}{llll}
\hline Parameters & \multicolumn{2}{l}{ Duck farmers $(\%)$} & \\
\cline { 2 - 4 } & Imo & Abia & Average \\
\hline How often do ducks fall sick & & & \\
Rarely/don't fall sick & 92.86 & 83.33 & 88.89 \\
Occasionally & 7.14 & 16.67 & 11.11 \\
Handling of sick ducks & & & \\
Treat sick ducks & 52.38 & 63.33 & 56.94 \\
Kill and consume & 7.14 & 6.67 & 6.94 \\
Do nothing & 16.67 & 6.67 & 12.50 \\
Sell sick ducks & 23.81 & 23.33 & 23.61 \\
Vaccination of ducks & & & \\
Yes & 0.00 & 0.00 & 0.00 \\
No & 100.00 & 100.00 & 100.00 \\
Access to veterinary services & & & \\
Yes & 0.00 & 0.00 & 0.00 \\
No & 100.00 & 100.00 & 100.00 \\
\hline
\end{tabular}

Accident from vehicles was identified as the primary cause $(45.45 \%)$ of mortality in ducks, as shown in Figure 2. Indeed, the extensive rearing system associated with the slow movement of ducks exposes them to death by careless motorists. This result collaborates with the findings of Duru et al. (2006) and Udedibie and Ogbonna (2006) that reported the main cause of mortality in ducks in Nigeria to be from automobiles. Again, predators (such as snakes, cats and irate neighbors whose farms have been destroyed by scavenging ducks) account for approximately $24.24 \%$ of deaths in ducks, while diseases account for about $16.16 \%$ of death in ducks. This result, however, is inconsistent with the reports by FAO (2009a) and Oguntunji and Ayorinde (2015) that disease was the main cause of mortality in ducks. However, Etuk et al. (2006), in another study, indicated that zero mortality in ducks can be achieved when ducks are reared in semi-intensive and intensive systems.

\section{Causes of duck mortality}

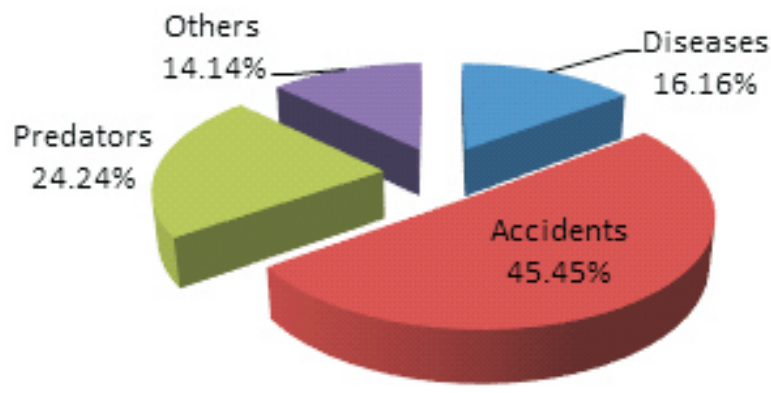

Fig. 2 Causes of duck mortality 


\section{Kadurumba, Egenuka, Ikpamezie, Kadurumba and Onunkwo}

\section{Constraints to duck meat consumption}

The myths surrounding ducks (62.28\%) constitute the main constraint against consumption of duck meat (Figure 3). The duck is raised and kept for traditional and sacrificial purposes only, allowing people to avoid them as a plague. This attitude makes the duck unpopular and its potential remains untapped. This report collaborates with the findings of Ogunjinmi et al. (2009) who reported various socio-cultural factors, religious beliefs, taboos and norms as dictating the consumption and use of several animals in a typical African society. Ola et al. (2003), in another study, reported that the duck was the most revered domestic bird in Nigeria and that its potential had not been exploited because of the many strange myths and taboos associated with it.

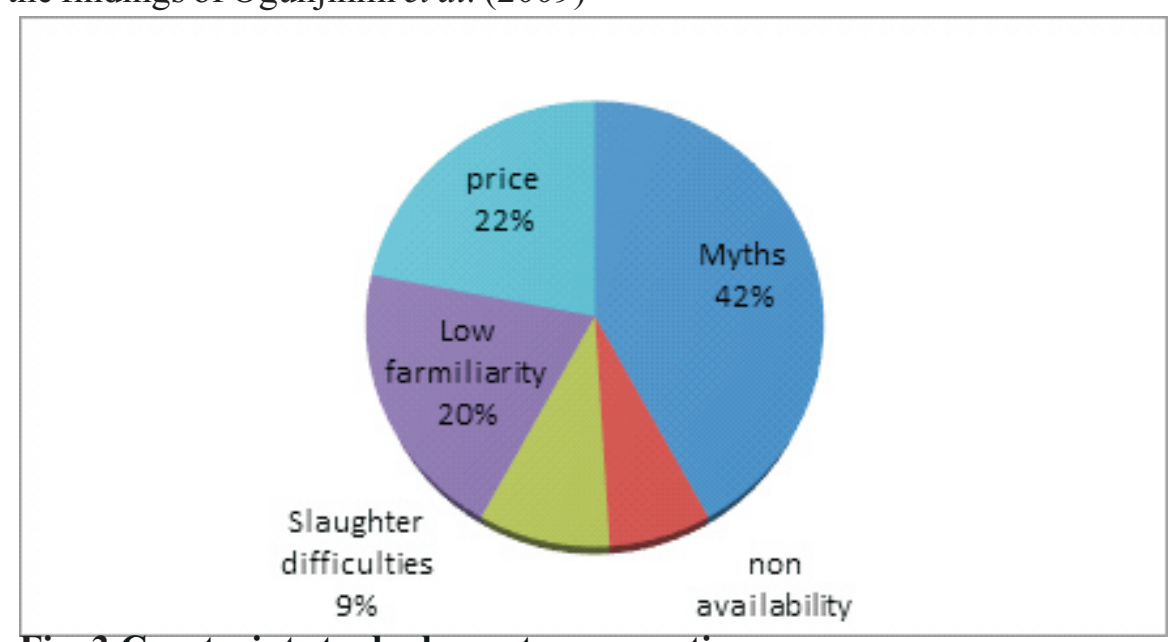

Fig. 3 Constraints to duck meat consumption

\section{Conclusion}

Duck farming is still practiced by only very few farmers and its production and improvement is hindered by myths and taboos that portrays it as a sacrificial and dirty bird. Efforts should be made to increase production and conservation by raising awareness of the potentials of the duck.

\section{References}

Adeyemi, O. A., Sobayo, R. A. and Aluko, F. A. 2008. A survey of duck farming activities in Abeokuta metropolis of Ogun State, Nigeria. Nigerian Poultry Science Journal, 5:23- 29.

Alfred, S. D. Y. and Agbede, J. O. 2012. Influencing factors of duck production in the Southwest of Nigeria. African Journal of Agricultural Resources, 7: 3498 3505.

Banga-Mboko, H., Lelou, B., Maes, D. and Leroy, P. L. 2007. Indigenous Muscovy ducks in Congo Brazzaville. Preliminary observations on indigenous Muscovy ducks reared under moderate inputs in Congolese conditions. Tropical Animal Health and Production, 39: 123-129.

Duru, S., Akpa, G. N., Sai'du, L., Olugbemi, T. S. and Jokthan, G. E. 2006. A preliminary study on duck management under periurban system. Livestock research for rural 
Evaluation of local duck production systems in Imo and Abia States of Nigeria

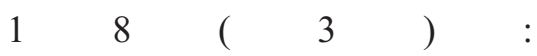

http://www.lrrd.org//rrd18/3/duru 18036.htm.

Etuk, I. F., Ojewole, G. S. and Abasiekong, S. F. 2006. Performance of Muscovy ducks under three management systems in Southeastern Nigeria. International Journal of Poultry Science, 5: 474-476.

Etuk, I. F., Ojewola, G. S., Akomas, S., Etuk, E. B. and Ogbuewu, I. P. 2011. Egg production potentials of Muscovy ducks (Cairina moschata) raised under three management system s in the humid tropics. Nigerian Journal of Animal Science, 13: 7075.

FAO, 1999. Food and Agricultural Organization Report of expert consultation on water fowl production in Africa. pp. 12.

FAO, 2009a. Characterization of domestic duck production systems in Cambodia. Prepared by Dinesh MT, Geerlings MT, Sölkner J, Thea $\mathrm{S}$, Thieme $\mathrm{O}$ \& Wurzinger $\mathrm{M}$. AHBL Promoting strategies for prevention and control of HPAI. Rome.

FAO, 2009b. Characterization of domestic chicken and duck production systems in Egypt. Prepared by Haitham M, Yakout MK, Olaf T. AHBL - Promoting strategies for preventionand control of HPAI. Rome.

Ige, A. O, Adedeji T. A, Ojedapo L. O \& Adewale A. O. 2014. Genetic evaluation of linear $\quad b \quad o \quad d \quad y$ measurement of local Muscovy ducks in the Derived Savannah Zone of Nigeria. Journal of Animal Science Advances, 4: 1045-1050.

Kadurumba, O. E., Okoli, I. C., Okere, P. C., Ikpamezie, L. C., Nwogu, C.
M., Egenuka, F. C. a n d Ngezelonye, I. F. 2015. Rural Production and Phenotypic $\mathrm{V}$ a r i a $\mathrm{t}$ o n $\mathrm{s}$ a m o n g indigenous ducks In Imo State Nigeria. International Journal of Agriculture and Rural Development, 18:2287-2291.

Mogesse, H. H. 2007. Phenotypic and genetic characteristics of indigenous chicken population in northern Ethiopia PhD. Dissertation submitted to Department of Animal a n d Wildlife and Grassland Service University of Free State Bloem Fountain, South Africa.

Morduzzaman, M., Bhuiyan, A. K. F. H., Rana, M., Islam, M. R. and Bhuiyan, M. S. A. 2015. Characterization and production potentials of Nageswari duck in Bangladesh. Bangladesh Journal Animal Science, 44: 92-99.

NBS (National Bureau of Statistics). 2010. Annual Abstract of Statistics, Abuja, Nigeria.

NRCRI 2017. Agro-Meteorology Unit. National Root Crop Research Institute, Umudike, Umuahia, Abia State, Nigeria.

Nwanta, J. A., Umoh, J. U., Abdu, P. A., Ajogi, I. and Ali-Balogun, J. K. 2006. Management of losses and Newcastle disease in rural poultry in Kaduna State. Nigerian Journal of Animal Production, 33: 274-285.

Nwaru, J. C. 2001. Stimulating entrepreneurship in Nigerian farms through sustainable agricultural extension system. Proceedings of the $7^{\text {th }}$ Annual conference of the Agricultural Extension Society of Nigeria. pp.19-27.

Nyoni, N. M. B. and Masika, P. J. 2012. Village chicken production practices in the Amatola Basin of 


\section{Kadurumba, Egenuka, Ikpamezie, Kadurumba and Onunkwo}

the Eastern Cape Province, South Africa. African Journal of Agricultural Research, 7:26472652.

Ogah, D. M. and Momoh, O. M. 2013. Village based indigenous Muscovy duck production in $\quad \mathrm{h} \mathrm{u} \mathrm{m} \mathrm{i} \mathrm{d}$ Savannah zone of Nigeria. Egyptian Poultry Science Journal, 32: 421-428.

Ogunjinmi, A. A., Lawal, M. O., Osunsina, I. O. O., Jayeola, O. A. and Salaudeen, M. 2009. Socio-cultural factors affecting snail consumption among ethnic groups in New Bussa, Niger State, Nigeria. In: Proceedings of the 33rd Annual Conference of the Nigerian Societyfor A n i m a l Science (NSAP) March, 2009, O 1 a b i s i O n a b a n jo University, Ago-Iwoye, Ogun State, Nigeria.pp.356-358.

Oguntunji, A. O. 2013. Phenotypic and biochemical characterization of the Nigerian Muscovy ducks. $\mathrm{Ph} . \mathrm{D}$ Dissertation. Bowen University. Iwo. Osun State. Nigeria.

Oguntunji, A. O. and Ayorinde, K. L. 2014. Sexual size dimorphism and sex determination by morphometric measurements in locally adapted Muscovy duck (Cairina moschata) in Nigeria. Acta 16 agriculturae Slovenic.

Oguntunji, A. O. and Ayorinde, K. L. 2015. Health management practices and reproductive performance of ducks in Nigeria. Journal of Agricultural Sciences, 60: 325-337.

Oguntunji, A. O., Oladejo, A. O. and Ayorinde, K. L. 2015. Seasonal variation in egg $\mathrm{p} \mathrm{r}$ o d u c t i o n and mortality of Muscovy ducks (Cairina moschata). Biotechnology in Animal Husbandry, 31: 181-192.

Okeudo, N. J., Okoli, I. C. and Igwe, G. O. F. 2003. Hematological characteristics of ducks (Cairina moschata) of Southeastern Nigeria. Tropicultura, 21: 61-65.

Okoli, I. C., Anyaegbulam, C. N., Etuk, E. B., Uchegbu, M. C. and Udedibie, A. B. I. 2004. S o c i o economic characteristics of poultry entrepreneurs in Imo State $\mathrm{Nigeria.Journal} \mathrm{of}$ Agriculture and Social Research, 4: $100-111$.

Ola, S. I. 2000. Vital reproductive and productive characteristics of the Nigerian Muscovy duck. Proceedings of 25th Annual NSAP Conference. pp.188-190.

Ola, S. I., Afisunlu, O. A. and Olatunde, J. O. 2003. Ethiological issues in the production of Muscovy duck in southwest Nigeria. Proceedings of the 2nd World Waterfowl Conference, 7- 9 October, 2003, Alexandra, Egypt. pp: 135 - 143.

Udedibie, A. B. I. and Ogbonna, R. C. 2006. On-farm evaluation of the growth of Muscovies $\mathrm{u} \mathrm{n} \mathrm{d} \mathrm{e} \mathrm{r}$ free range and confinement in South-eastern Nigeria. Nigerian Journal of Animal Production, 33: 268-273.

Ugbomeh, G. M. M. 2002. Socioeconomic characteristics of duck farmers in Ughelli North and south local government areas of Delta State of Nigeria: Implications for food security. Ghana Journal of Science, 42: 49- 60.

SPSS 2010. SPSS for Windows Release 10.01. SPSS Inc. Chicago.

Received: $12^{\text {th }}$ April, 2019

Accepted: $15^{\text {th }}$ June, 2019 